\title{
9. Sınıf Rehberlik Programının Öğrenci Görüşlerine Göre Değerlendirilmesi ${ }^{1}$
}

\author{
Doç. Dr. Aycan Çi̇çEK SAĞLAM* \\ Uşak Üniversitesi, Eğitim Fakültesi, Eğitim Bilimleri Bölümü, Uşak / Türkiye
}

\section{Çağla TOPÇU}

Bülent Ecevit Üniversitesi, Sosyal Bilimler Enstitüsü, Zonguldak / Türkiye

\section{$\ddot{O} z$}

$\mathrm{Bu}$ araştırmada, 9. sınıf rehberlik programının etkililik seviyesine ilişkin öğrenci görüşleri belirlenmeye çalışılmış ve bu görüşler 9. sınıf öğrencilerinin cinsiyet, okul türü, anne eğitim durumu, baba eğitim durumu ve okuldaki rehber öğretmen sayısına göre karşılaştırılmıştır. Çalışmada tarama modeli benimsenmiş olup Zonguldak il merkezine bağlı ortaöğretim kurumlarında öğrenim gören 488 lise öğrencisine araştırmacı tarafından geliştirilen veri toplama aracı uygulanmıştır. Faktör analizi sonu-

\footnotetext{
1 Bu makale, 2014 yılında Bülent Ecevit Üniversitesi, Sosyal Bilimler Enstitüsü, Eğitim Bilimleri Ana Bilim Dalı'nda Doç. Dr. Aycan ÇIÇEK SAĞLAM danıșmanlığında Çağla TOPÇU tarafından hazırlanan "9. Sınıf Rehberlik Programının Etkililik Düzeyinin Öğrenci Görüşlerine Göre Değerlendirilmesi” adlı yüksek lisans tezinden üretilmiştir

* Sorumlu Yazar. Tel: +905356204953Ｅ-posta: aycan.cicek@ usak.edu.tr

(C) 2015 Kalem Eğitim ve Sağlık Hizmetleri Vakfi. Bütün Hakları Saklıdır. ISSN: 2146-5606
} 
cunda beş alt boyuttan oluşan ölçeğin güvenirlik düzeyi 0.962 olarak bulunmuştur. Toplanan veriler normal dağılım göstermediği için parametrik olmayan testlerden Mann Whitney U ve Kruskal-Wallis H testleri uygulanmıştır. Araştırma sonuçlarına göre, 9. sınıf öğrencileri rehberlik programında yer alan eğitsel, meslekî ve kişisel rehberlik hizmetlerini kısmen etkili bulmaktadırlar. Anadolu öğretmen lisesi öğrencileri diğer lise öğrencilerine göre, uygulanan rehberlik programını daha yararlı bulmaktadırlar. Ayrıca anne-baba eğitim durumlarına göre de rehberlik programını etkili ve yararlı bulma durumları farklılık göstermektedir. Hizmetlerin yeterlilik seviyesinin yükseltilebilmesi için; okullardaki rehber öğretmen sayısı ile rehberlik etkinliklerine ayrılan süre arttırılabilir. Ayrıca okuldaki idareci ve öğretmenlere rehberlik bilinci kazandıracak hizmet içi eğitimler düzenlenerek, rehberlik programlarından üst seviyede fayda sağlanabilir.

Anahtar Kelimeler: Rehberlik program; Program değerlendirme; Rehberlik hizmetleri; Öğrenci görüşleri; Eğitsel program.

\title{
$9^{\text {th }}$ Grade Students' Opinions About The Effectiveness Of Guidance Programs
}

\begin{abstract}
In the present study, ninth grade students' opinions about the effectiveness of guidance programs were gathered and examined in respect to the following variables: gender, school-type, mother-father education level, the number of guidance teachers at the school. Adopting a survey research design, a data collection instrument developed by the researcher was applied to 488 high school students from the city center of Zonguldak. The factor analysis yielded a five-factor solution and the reliability coefficient of the scale was found to be 0.962 . Since the normality assumption was violated, non-parametric tests (Mann-Whitney U tests and Kruskal-Wallis H tests) were conducted. Research findings showed that $9^{\text {th }}$ grade students found the educational, vocational, and personal guidance services as somewhat effective. Students from the Anatolian teacher high schools found the implemented guidance programs more beneficial compared to other high
\end{abstract}


school students. Moreover, student' perceptions of effectiveness of the guidance programs differ by mother-father education level. In order to increase the effectiveness of the programs, the number of guidance teachers and the amount of time spent for the guidance services may be increased. In addition, providing in-service training to school administrators and teachers would enhance the effectiveness of the guidance programs.

Keywords: Guidance programs; Program evaluation; Guidance services; Student opinions; Educational programs.

\section{Extended Summary}

\section{Purpose}

In this survey, it is aimed to put forvard the definition of the students' views regarding the effectiveness level of $9^{\text {th }}$ grade counselling program and whether these views undergo a chance in respect to variables of $9^{\text {th }}$ grade students' gender, type of school, mother's educational level, father's educational level and the guidance counsel or numbers at school.

\section{Method}

In this survey, descriptive survey model (Descriptive method) has been used. Cosmos of survey is constituted by total of 1714 students studying of $9^{\text {th }}$ grade during 2011-2012 academic year in 16 secondary eduation schools located in the central town of city of Zonguldak, 488 (27.35\%) of those students have been taken into the sampling. School Counselling Program Evaluation Scale developed by researcher has been used in this survey. Constituted by two sections, survey scale is a quintet likert type. While personal information consisting of five entries is in the first section, statements regarding $9^{\text {th }}$ grade counselling prog- 
ram, consisting of 41 entries is placed in the second section. The data obtained from questionnaires have been analyzed on SPSS 17.0 packaged software. When the distribution of obtained data is analyzed, since the data do not disclose normal distribution, the tecniques being not parametric (non-parametric), Mann Whitney U and Kruskal-Wallis $\mathrm{H}$ tests have been used.

\section{Results}

When the differentiation level of the personal counselling services according to various factors which are placed in the $9^{\text {th }}$ grade counselling program of the students participating in the survey are examined, any meaningful variety with regards to variables of the gender and the number of guidance counselor at school has not been found out. As for the point of view of the variety of school-type, it has been deduced that Anatolian Teacher High School students find personal counselling services more beneficial than other high school students. When it has been examined with regards to mother's educational level, father's educational level, it has been understood that those students whose mothers and fathers have a secondary school degree find personal counselling services more beneficial, and they are followed by those whose mothers and fathers have a primary school degree.

When it comes to the extent of occupational counselling services, it has been deduced that Anatolian Teacher High School students find occupational counselling services more benefical than other high school students. When findings are examined in the extent of mothers' education levels, it has been deduced that those students whose mothers 
have a primary school degree find occupational counselling services more benefical, and they are followed by those whose mothers have a secondary school degree. When findings are examined according to fathers' education levels, it has been deduced that those students whose fathers have a high school degree find occupational counselling services more benefical.

In the extent of educational counselling services, with regards to school-type, it has been understood that Anatolian Teacher High School students find educational counselling services more beneficial than other high school students. When findings are examined according to fathers' education levels, it has been deduced that those students whose fathers have a secondary school degree find occupational counselling services more benefical.

In the extent of guidance counselling, with regards to school-type, when compared to other high school students, Anatolian Teacher High School students have viewed that school and class teachers are much more effective.

When the differentiation level in the extent of school conditions according to various factors is examined, those students whose mothers have a primary school degree find the conditions more adequate dealing with applying program of the school than others.

\section{Conclusion}

As a consequence of the survey, it has been observed that collaboration can not be fullfilled in adequate level. For being able to make it 
more productive, it has been seen necessary that collaboration should completely be achieved, teachers should fully be informed, guidance counsellors are to be more active and counselling services are to be permanent and effective.

\section{Giriş}

21. yüzyılla birlikte teknoloji alanındaki değişimlerin de hızla artması kaçınılmaz gözükmektedir. Teknolojideki bu hızlı değişimlerin olumsuz etkilerinden insanlığın zarar görmemesi ve dahası değişime uyum sağlayabilmesi eğitim sayesinde başarılacaktır (Oğuz, Oktay ve Ayhan, 2010). Eğitim sistemi değişimin gerektirdiği insan tipini yetiştirmede etkili olmalıdır. Hazırlanacak eğitim programları bireyin ve toplumun ihtiyaçlarını dikkate alarak gelişimlerini sağlamada yardımcı olmak durumundadır. Alışılagelmiş eğitim sisteminde okulların yalnızca akademik başarıya önem verdiği, dolayısıyla bireyin kendini geliştirmesine olanak vermediği, kalıcı ve köklü davranış değiş̧ikliği sağlayamadığı, bireysel farklılıklar göz ardı edildiğinden yetenek ve ilgilerinin gelişemediği açıkça görülmektedir. $\mathrm{Bu}$ durumun sonucu olarak da yeni fikirler ve gelişimler doğrultusunda eğitimde çağdaş adımlar atılmaya başlanmış ve rehberlik hizmetleri okullarda yerini almıştır (Yeşilyaprak, 2001).

Kuzgun (1991) rehberliği bireyin kendini anlaması, çevresinde var olan olanakların farkına varması ve kendine uygun kararlar vererek kendini gerçekleştirebilmesi için yapılan sistemli ve profesyonel yardım süreci olarak tanımlanmaktadır. Birey hayatı boyunca kendisini ve 
çevresini etkileyecek kararlarla karşı karşıyadır ve bu dönemde kaygı ya da bunalım yaşayabilir. Böyle dönemlerde rehberlik hizmetlerinin sağlayacağı psikolojik desteğe ihtiyaç duyabilir (Girgin, 2012).

Okullardaki rehberlik hizmetleri öğrencilerin kişisel, eğitsel ve meslekî alanlarda gelişimlerini ve uyum sağlamalarını temele almaktadır. Eğitsel rehberlik ve danışma, bir bireyin öğrenimle ve öğrenme ile ilgili olarak karşılaştığı problemlerle uğraşır (Tan, 1992, s.104). Eğitim kademesinin bütün merhalelerinde, psikolojik danışmanlardan beklenen en önemli görev, öğrencilerin gelecek meslek ve kariyerlerine yönelik seçimler, kararlar ve hazırlıklarda yardımcı olmalarıdır (Yeşilyaprak, 2011). Kişisel rehberlik ise, bireyin kendini çeşitli yönleriyle gerçekçi bir şekilde tanıyıp kabullenmesi; içinde yaşadığı çevreyi sağlıklı bir biçimde algılayıp değerlendirebilmesinin yanında, kendi yeteneklerini en iyi biçimde kullanabilmesine ve bireysel problemlerini tanımalarına bu problemlerini çözmede kendi kendilerine yeter duruma gelmelerine yardım etme sürecini kapsar (Aydın, 1998).

Günümüzde bireyin, okul öncesinden üniversiteye kadar olan eğitim yolculuğunda okul rehberlik servisleri önemli bir rol üstlenmişlerdir. Eğitimin hangi kademesinde olursa olsun rehberlik hizmetleri, psikolojik danışma, yöneltme, bilgi verme, bireyi çeşitli yönleriyle tanıma ve kendisinin de tanımasına olanak sağlama gibi hizmet alanlarını kapsamaktadır. Öğrenciler zaman zaman zorlandığı durumlarda ve gelişmek istediğinde bir danışmandan psikolojik danışma hizmeti alabilmeli, ilgi ve yetenekleri doğrultusunda olan alanlara yöneltilmeli, okullarda öğrencilerin çeşitli program ve eğitsel kollara ayrılmasına ve 
kendisine uygun bir mesleği seçebilmesine yardım edilmelidir (Akbaba, 2004).

Rehberlik programları okulun türü, bulunduğu sosyo-kültürel çevre, okulun imkânları, öğrencilerin gelişimsel özellikleri gibi noktalar dikkate alınarak okul rehber öğretmeni tarafından hazırlanır. Hazırlanan program Rehberlik ve Psikolojik Danışma Hizmetleri Okul Yürütme Komisyonu tarafından incelenir ve onaylanır. Her şubedeki sınıf rehber ögretmeni, okul geneli için hazırlanan yıllık rehberlik programı doğrultusunda kendi şube öğrencileri için yıllık rehberlik hizmetleri çalışma plânını hazırlar. Sınıf rehber öğretmenleri rehberlik ve psikolojik danışmanlık çalışmalarının öğrencilerin kişisel gelişimini destekleyici önemli bir parçasıdır (Karaca ve İkiz, 2014).Yıl boyunca hem okul programında hem de şube programlarında daha önceden öngörülemeyen değişiklikler yapılabilir (Çam, 2005). Rowley, Stroh, Heather ve Christopher (2005)'a göre göre rehberlik müfredâtı kapsamlı gelişimsel rehberlik programının merkezinde yer alır. Çünkü bu programda okuldaki bütün öğrencilere hizmet vermek önemlidir. Okuldaki bütün öğrencilere ulaşmak, gerekli yeterlikleri kazandırmak çok güç olduğundan bu çalışmalar sınıflarda grup rehberlik etkinlikleri şeklinde yürütülmektedir.

Rehberlik programlarının hazırlanmasında da yıllar içinde bazı değişimler yaşanmıştır. Krize yönelik danışma, bilgilendirme hizmeti, görev öncelikli, yapılanmamış bir yapı gösteren geleneksel rehberlik anlayışı yerini 1970'li yıllardan sonra gelişimsel yaklaşıma bırakmıştır. Ardından gelişen sistem yaklaşımı, toplam kalite ve stratejik plânlama 
akımlarının etkisiyle "kapsamlı gelişimsel rehberlik programı" yaklaşımı geleneksel rehberlik anlayışının yerini almıştır. Kapsamlı programlama rehberlik hizmetlerini eğitimi oluşturan sistemlerin bir parçası olarak ele almaktadır. Yaşanan bu gelişmelerle rehberlik hizmetlerinden beklentilerin de çeşitlendiği görülmektedir. Modo, Sanni, Uwah ve Mogbo (2013); Chireshe (2006) ve Başaran (2008) çalışmalarında okul rehberlik servislerinden beklentilerin akademik başarı, meslek seçimi ve davranış problemlerinin giderilmesi yönünde olduğunu, rehberlik hizmetlerinin öğrencilerin çeşitli yönlerini geliştirmede etkili olduğunu ortaya koymuşlardır.

Kapsamlı gelişimsel rehberlik programları hazırlanırken programın amaçları, okulun eğitime bakış açısı ve eğitimden beklentileri, psikolojik danışma ve rehberlik hizmetlerinin ilkeleri ve öğrencilerin ihtiyaçları göz önüne alınmalıdır. Bu nedenle her eğitim kademesine göre hazırlanacak programlar birbirine göre farklılık gösterecektir. Bununla beraber kapsamlı gelişimsel rehberlik programlarının nasıl geliştirileceği, içeriğinin neler olacağ1 ve nasıl değerlendirileceği gibi konularda rehber öğretmenlerin yararlanabilecekleri kaynaklar sınırlıdır. Okul rehberlik servisleri genelde Rehberlik Araştırma Merkezleri tarafından hazırlanan taslak niteliğinde olan çerçeve programları kullanmaktadır. Bu çerçeve programlar okul türleri gözetilmeksizin okul öncesi, ilkokul ve ortaokul olarak hazırlanmaktadır. Oysaki ortaöğretim kurumları olan liseler genel lise, anadolu lisesi, fen lisesi, meslek lisesi gibi pek çok türlere ayrılmaktadır. Okul rehberlik servisleri merkezden gönderilen çerçeve programları kendi okul türleri ve öğrenci ihtiyaçla- 
rına göre yeniden hazırlamalıdırlar. Kapsamlı gelişimsel rehberlik programlarını uygulayabilmek için öğrencinin gelişimi öncelikli, program odaklı, kişilik eğitimi anlayışını temel alan bir anlayış benimsenmiş olmalıdır. Okul psikolojik danışmanları program geliştirmeyle ilgili yeterli donanıma sahip olmamaları, okulun diğer öğretmenlerinin de çoğunluğunun rehberlik konusunda eğitim almamış olmaları bu programların uygulanabilirliğinin önünde engel oluşturmaktadır. Ayrıca programların önemli bir kısmını sınıf rehberliği yoluyla kazandırılacak içerik oluşturur. Sınıf rehberliğinin uygulanabilmesi için ders saati ayrılması gerekmektedir. Ancak bugün geçerli olan eğitim sistemimizde ortaokulun 6. sınıfına kadar rehberlik saati yoktur. Kapsamlı gelişimsel rehberlik programının merkezinde önemli bir rol oynayan okul rehber öğretmenlerinin sayıca yetersiz olması da programın önündeki bir diğer engeldir (Külahoğlu, 2004). Berber (2010), Dahir, Burnham ve Stone (2009), Hatipoğlu (2010), Lapan, Gysbers ve Sun (1997), Tüfekçi (2011), çalışmalarında rehberlik programlarının içerdiği hizmet alanlarının çeşitlilik gösterdiğini ortaya koymakla birlikte, uygulama şartlarının programı önemli seviyede etkilediğini vurgulamışlardır.

Ortaöğretim Rehberlik ve Yönlendirme Dersi Programı, Okul Psikolojik Danışma ve Rehberlik Programı değil, onun bir parçasıdır. Programdaki etkinlikler Kapsamlı Gelişimsel Rehberlik Programları dikkate alınarak, kazanımların gerçekleşmesi için hazırlanmıştır. Programda her sınıf seviyesi için 30 haftalık etkinlik sunulmuş, kalan 6 haftada ise diğer rehberlik faaliyetlerine ayrılmıştır. Bütün okullarda 
aynı etkinliklerin kullanılması zorunlu olmamakla birlikte kazanımlara bağlı kalınıp farklı etkinliklere de yer verilebilmektedir. Okul rehberlik servisleri farklı okul türlerine göre ve okulun ihtiyaçlarına uygun olan etkinliklere yer verebilmektedirler (MEB, 2011). Okul rehberlik servislerinin işlevselliği ve okul eğitim personelinin programın uygulanması sırasındaki işbirliği rehberlik programlarının başarısını arttıracaktır. Aluede ve Egbochuku (2009), Muango ve Joel (2012), Selen (2008), Şahin (2006) de çalışmalarında eğitim kurumlarındaki öğrencilerin rehberlik servislerinden yeterli seviyede yararlanmaları gerektiğinin önemini vurgulamışlardır.

Ortaöğretim 9. sınıf öğrencilerinin yaş özellikleri (14-15 yaş) incelendiğinde bu dönem asıl olarak ergenlik dönemi özelliklerini kapsamaktadır. Bu yaş grubu öğrencileri kimlik kazanmaya karşı rol karmaşası içindedirler. Yetişkin mi çocuk mu, bocalamaları içinde sıklıkla "Ben kimim?" sorusunun cevabını ararlarken anne-babasından çok akran gruplarından etkilenirler. Hızlı bir fiziksel değişim içindeyken aynı anda kendisini, gelecekteki eğitimi ve meslekî gelişimi hakkında yeni kararlar verme baskısı içinde bulabilirler (Senemoğlu, 2011). Bu açılardan bakıldığında ortaöğretimin ilk kademesini oluşturan 9. sınıf oldukça önem kazanmaktadır. Ortaöğretime geçiş sınavlarının yoğun etkisinden sonra 9. sınıfı bir mola merhalesi olarak görmekte olan genç akademik başarısızlıkla karşı karşıya kalmaktadır. Bununla beraber yükseköğretime öğrenci seçme sınavlarından olan Yüksek Öğretime Geçiş Sınavı (YGS)'nin kapsamı ağırlıklı olarak 9. sınıf müfredatından oluşmaktadır. Öğrenci bu dönemde yoğun bir 
akademik destek ve eğitsel rehberliğe ihtiyaç duymaktadır. Ortaöğretimde öğrenci 10. sınıfa geçerken ileride yöneleceği yükseköğretim programlarına temel sağlayacak olan dersleri seçmek durumundadır. $\mathrm{Bu}$ nedenle de ilgi, yetenek ve kişilik özelliklerini yakından tanıyabilmesi, geleceği için doğru kararları verebilmesi gerekmektedir. Ortaokuldan sonra kendisi için yeni bir okul olan lisede okul ortamına alışamama ya da yabancılaşma gibi problemler yaşayabileceğinden yeterli bir oryantasyon (uyum alıştırmaları) hizmeti verilmelidir. 9. sınıf rehberlik programı öğrenciye ihtiyacı olan desteği vermekle yükümlüdür ve bu açıdan önemlidir. Yürütülen bu çalışmada, 9. sınıf rehberlik programının yararlanıcısı durumunda olan öğrencilerin program hakkındaki görüşleri incelenmek önemli görülmüştür.

Tokalı (2007), 9. sınıf rehberlik programı ile ilgili yürüttüğü araştırmasında; rehber öğretmenlere göre 9. sınıf rehberlik programındaki kazanımların yeterli seviyede kazandırılamadığı belirlenmiştir. Bunun nedeni olarak da uygulamadan kaynaklı sorunlar olduğu belirtilmiştir. Programın işlevsel olabilmesi için, kavramların açıklanması gerektiği, bilgi vermenin yanında uygulamaya da önem verilmesi gerektiği ve sınıf öğretmenlerinin rehber öğretmenle işbirliği yapması gerektiği vurgulanmıştır.

Hıdır (2010)'ın, orta öğretimde öğrencilere sunulan rehberlik programının kazanımlarının amacına ulaşma seviyesine ilişkin yürüttüğü araştırmasının sonuçlarına göre; öğrencilerin sınıf seviyelerine göre çeşitli yeterlik alanlarına ait kazanımları kazanma seviyelerinin farklılık gösterdiği anlaşılmıştır. Örneğin 9. sınıflar 10. sınıflara göre, 
10. sınıflar da 11. sınıflara göre kazanımları daha iyi kazandığı anlaş1lmıştır. Okul türlerine göre incelendiğinde ise anadolu lisesi öğrencilerinin meslek lisesi öğrencilerine göre kazanımları daha iyi kazandıkları görülmüştür. Okullardaki öğrenci sayıları da arttıkça kazanım seviyelerinin düştüğü ulaşılan sonuçlar arasındadır.

Tüfekçi (2011), kapsamlı psikolojik danışma ve rehberlik programında bulunan rehberlik etkinliklerinin sınıf rehber öğretmenleri ve rehber öğretmenler tarafından kullanılma durumlarına ilişkin betimsel bir araştırma yürütmüştür. Araştırma sonucuna göre, sınıf rehber öğretmenleri ve rehber öğretmenler bütün sınıf seviyelerindeki rehberlik etkinliklerinde bulunan soruların öğrenciler tarafindan kolayca yanıtlandığını, etkinliklerin öğrencilerin gelişim seviyesine uygun olduğunu, etkinlikler için uygun bir sınıf ortamı olduğunu ve etkinliklerde bulunan formların kolayca doldurulduğunu belirtmişlerdir. İlköğretim birinci kademe sınıf rehber öğretmenleri ikinci kademe sınıf rehber öğretmenlerine göre etkinlikler için ayrılan sürenin yeterli olduğunu, öğrencilerin etkinliklere katılmada istekli olduğunu kalabalık sınıflarda uygulama yapmanın zor olmadığını belirtmişlerdir.

Bu bağlamda, 9. sınıf rehberlik programının etkililik seviyesine ilişkin öğrenci görüşlerinin belirlenmesi ve bu görüşlerin 9. sınıf öğrencilerinin cinsiyet, okul türü, anne eğitim durumu, baba eğitim durumu ve okuldaki rehber öğretmen sayısı değişkenlerine göre farklılaşıp farklılaşmadığını ortaya koymak bu çalışmanın amacını oluşturmaktadır. 


\section{Yöntem}

\section{Araştırma Deseni}

$\mathrm{Bu}$ araştırmada 9. sınıf rehberlik programına ilişkin görüşleri inceleme amaçlandığından, tarama modeli kullanılmıştır. Tarama araştırmaları, bir konuya ya da olaya ilişkin katılımcıların görüşlerinin ya da ilgi, beceri, yetenek, tutum vb. özelliklerinin belirlendiği genellikle diğer araştırmalara göre daha büyük örneklemler üzerinde yapılan araştırmalardır (Büyüköztürk, Çokluk ve Köklü, 2011).

\section{Evren ve Örneklem}

Araştırmanın evrenini Zonguldak merkez ilçedeki 16 ortaöğretim kurumunun 2011-2012 Eğitim-Öğretim Y1lı'nda 9. sinıfta okuyan toplam 1714 öğrencisi oluşturmaktadır.

Araştırma evrenindeki okullar okul türüne göre farklılık gösterdiğinden, bu okulların beş okul türüne (genel lise, fen lisesi, meslek lisesi, anadolu lisesi, anadolu öğretmen lisesi) göre gruplandırılması yapılmıştır. İl merkezi genelinde genel lise, fen lisesi ve anadolu öğretmen lisesi türlerinde birer okul bulunduğundan, mevcut okullar, örnekleme doğrudan alınmıştır. Anadolu lisesi ve meslek lisesi de basit seçkisiz örnekleme yöntemiyle, araştırmanın örneklemine dâhil edilmiştir. Basit seçkisiz örnekleme; her bir örneklem seçimine eşit seçilme olasılığı vererek seçilen birimlerin örnekleme alınmasıdır. Burada her örneklem birimine eşit seçilme olasılığı verilmesinin anlamı, örneklem uzaydan her bir örneklemin eşit olasılıkla seçilmesidir (Büyüköztürk, vd., 2011). Araştırma evrenini oluşturan 16 ortaöğretim okulundan 1714 öğrencinin 488’i (\%27.35) örnekleme alınmıştır. 


\section{Veri Toplama Aracı}

Araştırmada araştırmacı tarafından geliştirilen Okul Rehberlik Programı Değerlendirme Ölçeği kullanılmıştır. Ölçek, iki bölümden oluşmaktadır. Birinci bölümde 5 maddeden oluşan kişisel bilgiler, ikinci bölümde ise 41 maddeden oluşan 9. sinıf rehberlik programına ilişkin ifadeler yer almaktadır. Geliştirilen ölçek 5'li likert tipi ölçektir. Veri toplama aracı geliştirilmeden önce ilgili literatür taranarak 9. sınıf rehberlik programına ilişkin yürütülen çalışmalar incelenmiştir. 9. sinıflarda yürütülmesi gereken rehberlik hizmetleri ve alanda çalışan 4 rehber öğretmenin görüşleri doğrultusunda maddeler oluşturulmuştur. $\mathrm{Bu}$ maddeler üzerinde çalışılarak 33 maddelik bir soru havuzu oluşturulmuştur. Ardından ölçek, 4 rehberlik ve psikolojik danışmanlık anabilim dalı öğretim elemanına, 1 psikoloji ve 1 eğitim yönetimi, teftişi, plânlaması ve ekonomisi anabilim dalı öğretim elemanlarına gönderilerek uzman görüşüne sunulmuştur. Uzman görüşleri alındıktan sonra ölçeğin madde sayısı 41 'e çıkarılmıştır.

Ölçeğin 488 öğrenciye uygulanmasının ardından faktör analizi yapılmıştır. Faktör analizi, aynı yapıyı ya da niteliği ölçen değişkenleri bir araya toplayarak ölçmeyi az sayıda faktör ile açıklamayı amaçlayan bir istatistiksel tekniktir. Öncelikle maddelerin tek bir faktörde yüksek yük değerine, diğer faktörlerde ise düşük yük değerlerine sahip olmasına bakılmalıdır. Bir maddenin yüksek yük değeri, verdiği faktörün dışında ikinci bir faktörle verdiği yük değeri arasındaki farkın mümkün olduğunca yüksek olması beklenir. Yüksek iki yük değeri arasındaki farkın en az 0.10 olması önerilmektedir. Çok faktörlü bir yapıda birden 
çok faktöre yüksek yük değeri veren madde, binişik bir madde olarak anılır ve ölçekten çıkarılması gerekebilir (Büyüköztürk, 2011). Bu açıdan hareketle ölçekte bulunan 6. madde iki faktörden aldığg değerler 0.473 ve 0.378 ve farkları 0.10 'dan küçük olduğundan, 7. maddenin iki faktörden aldığ 1 değerler 0.403 ve 0.473 ve farkları 0.10 'dan küçük olduğundan, 8. maddenin iki faktörden aldığı değerler 0.405 ve 0.463 ve farkları 0,10'dan küçük olduğundan, 24. maddenin üç faktörden aldığ1 değerler $0.416,0.388$ ve 0.343 farkları da 0.10 'dan küçük olduğundan bu maddeler ölçekten çıkarılmıştır. Bu işlemin ardından oluşan faktör yük değerleri tablosunda 34. ve 35. maddeler tek bir faktör oluşturduğundan bu maddeler de ölçekten çıkarılmıştır. Sonuç olarak ölçek 35 madde 5 boyut üzerinden değerlendirilmiştir. Aşağ1daki tabloda faktör analizi sonucunda ölçekte yer almasına karar verilen maddeler ve faktör yük değerleri verilmiştir.

Verilerin faktör analizi için uygunluğu Kaiser-Meyer-Olkin (KMO) katsayısı ve Bartlett küresellik testi ile incelenebilir. KMO'nun 0,60’tan yüksek çıkması beklenir. Bartlett testi, değişkenler arasında ilişki olup olmadığını kısmi korelasyonlar temelinde inceler. Hesaplamanın anlamlı çıkması, veri matrisinin uygun olduğunun göstergesidir (Büyüköztürk, 2011). Faktör analizi sonucu elde edilen boyutlar; kişisel rehberlik, meslekî rehberlik, eğitsel rehberlik, rehber öğretmen ve okulun şartları şeklinde oluşturulmuştur. KMO değeri 0.962 ve Bartlett testi 0.000 seviyesinde anlamlı bulunmuştur. Ölçeğin güvenilirlik analizi için 6 madde çıkarıldıktan sonra kalan 35 madde için yapılan Cronbach's Alfa analizinde güvenilirlik katsayısı 0.962 olarak 
bulunmuştur. 5 alt boyut için Cronbach's Alfa güvenilirlik katsayısı; kişisel rehberlik alt boyutu 0.814, meslekî rehberlik alt boyutu 0.810, eğitsel rehberlik alt boyutu 0.832 , rehber öğretmen alt boyutu 0.843 ve okulun şartları alt boyutu için de 0.875 olarak bulunmuştur. Verilerin çözümlenmesi ve yorumlanmasında 5'li ölçek aralıkları 0.80 (5-1=4 ve $4 / 5=0,80$ ) arasında eşit aralıklar olarak aşağıdaki gibi belirlenmiştir:
5. Tamamen kat1lyorum
4.20-5.00
4. Kat1liyorum
$3.40-4.19$
3. Kismen kat1liyorum
2.60-3.39
2. Katılmiyorum
1.80-2.59
1. Kesinlikle katılmıyorum
$1.00-1.79$

Tablo 1. Faktör Analizi Sonucunda Ölçekte Yer Almasına Karar Verilen Maddeler ve Faktör Yük Değerleri

Madde

12 Bedensel sağlığım için gerekli alışkanlıkları edinmemde yararlıdır. 0.64

11 Ergenlik döneminin bedensel ve duygusal değişimlerin ortaya ç1- $\quad 0.63$ kardığı durumlara uyum sağlamamda etkilidir.

14 Öfke ile baş etme yollarını öğrenmemi sağlar.

0.61

15 Kişiler arası ilişkilerde anlaşmazlıkları çözebilmem açısından yararlıdır. $\quad 0.60$

13 Kişilerarası iletişimimi güçlendirmem açısından yararlıdır. $\quad 0.60$

19 Duygusal ve sosyal uyum sorunlarının çözümünde etkilidir. $\quad 0.59$

16 Akran baskısıyla baş edebilme becerilerini geliştirmemde yararlıdır. 0.59

21 Karşı cinsle ilişkilerimde yaşadığım sorunlarla başa çıkmamda etkilidir. $\quad 0.58$

20 Karşılaşı̆ı̆ım sorunların çözümünde gereken yardımı alabilmemi sağlar. $\quad 0.55$

17 Okulda sorunların ortaya çıkmadan önlenmesinde etkilidir. 0.53
} 
23 Özgüven ve özsaygımı geliştirmem konusunda etkilidir. 0.52

22 Sosyal beceri geliştirmem konusunda etkilidir. 0.52

10 Sınav kaygısıyla baş edebilmemde etkilidir. $\quad 0.50$

18 Eğitim-öğretim etkinlikleri içindeki grup çalışmalarına aktif olarak $\quad 0.49$ katılmamı sağlar.

9 Okulda yararlanabileceğim imkânlar hakkında bilgi sahibi olmamı sağladı. 0.46

31 Seçebileceğim meslekleri tanımam açısından yararlıdır. $\quad 0.70$

27 Seçebileceğim dersler ile meslekler arasındaki ilişkiyi fark etmemi $\quad 0.70$ sağlar.

28 Meslekî değerlerimi fark etmemi sağlar. $\quad 0.66$

29 İlgilerimi tanımamı sağlar. $\quad 0.64$

32 Geleceğe ilişkin hedef belirlememde etkilidir. $\quad 0.64$

33 Meslek ve kariyer imkânlarım hakkında doğru ve kapsamlı bilgiye $\quad 0.61$ ulaşmamı sağlar.

30 Yeteneklerimi tanımamı sağlar. $\quad 0.60$

26 Bana uygun olan dersleri seçmemin önemini kavramamı sağlar. $\quad 0.60$

25 Okulda seçebileceğim dersler hakkında bilgi sahibi olmamı sağlar. $\quad 0.50$

\begin{tabular}{|c|c|c|c|}
\hline \multirow{5}{*}{ 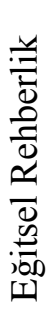 } & 2 & Akademik başarımı artırmam açısından yararlıdır. & 0.72 \\
\hline & 3 & Ders çalışma alışkanlığı kazanabilmem açısından yararlıdır. & 0.72 \\
\hline & 1 & Öğrencileri ilgilendiren yönetmelikleri tanımam açısından yararlıdır. & 0.66 \\
\hline & 4 & Verimli ders çalışma tekniklerini öğrenmemi sağlar. & 0.63 \\
\hline & 5 & $\begin{array}{l}\text { Okul çevresindeki eğitsel ve sosyal imkânlardan haberdar olmamı } \\
\text { sağlar. }\end{array}$ & 0.42 \\
\hline \multirow{3}{*}{ 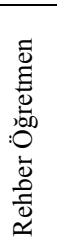 } & 37 & $\begin{array}{l}\text { Sınıf rehber öğretmenleri öğrencilerin, kişisel-sosyal gelişimlerini } \\
\text { ve ders başarılarını takip edebilmektedir. }\end{array}$ & 0.74 \\
\hline & 36 & Sınıf rehber öğretmenleri, rehberlik etkinliklerini uygularken isteklidir. & 0.64 \\
\hline & 38 & $\begin{array}{l}\text { Okul rehber öğretmenleri öğrencilerin, kişisel-sosyal gelişimlerini } \\
\text { ve ders başarılarını takip edebilmektedir. }\end{array}$ & 0.49 \\
\hline \multirow{3}{*}{ 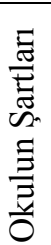 } & 40 & Okuldaki rehber öğretmen sayısı yeterlidir. & 0.67 \\
\hline & 41 & $\begin{array}{l}\text { Rehberlik etkinliklerini uygulayabilmek için haftada bir (1) ders } \\
\text { saati yeterlidir. }\end{array}$ & 0.51 \\
\hline & 39 & $\begin{array}{l}\text { Okul idaresi, rehberlik programının uygulanmasında destekleyici ve } \\
\text { yardımcıdır. }\end{array}$ & 0.43 \\
\hline
\end{tabular}




\section{Verilerin Analizi}

Zonguldak İl Millî Eğitim Müdürlüğü’nden araştırma izni alınarak, Zonguldak il merkezindeki 2012-2013 Eğitim-Öğretim Y1lı'nda beş ortaöğretim kurumunda öğrenim gören 10. sınıf öğrencilerine anket uygulanmıştır. Bu öğrenciler 2011-2012 Eğitim-Öğretim Yılı’nda 9. sınıfta okuyup o yılın rehberlik programı kendilerine uygulanmış öğrencilerdir. Anketlerin okul rehber öğretmenleriyle birlikte uygulanması sağlanmıştır. Toplamda 525 öğrenciye anket uygulanmış, bunlardan hatalı ve eksik olan 37 anket çıkarılıp toplam 488 anket analize dâhil edilmiştir.

Anketlerden elde edilen veriler SPSS 17.0 paket programında analiz edilmiştir. Verilerin analizinde aşağıdaki istatistiksel işlemler uygulanmıştır. Toplanan verilerin dağılımları incelendiğinde $p=0.00$ olduğundan ve $p<0.05$ olduğu için verilerin normal dağılım göstermediği görülmüştür. $\mathrm{Bu}$ nedenle parametrik olmayan (non-parametrik) teknikler kullanılmıştır. Parametrik istatistikler ilgilenilen değişken bakımından ölçümlerin evrendeki dağılımlarıyla ilgili bazı varsayımları gerektiren, buna karşılık parametrik olmayan istatistikler böyle bir varsayım gerektirmeyen dağılıma bağlı olmayan istatistiklerdir. Parametrik olmayan istatistikler ölçeklerin bütününden elde edilen veriler üzerinde kullanılabilir (Büyüköztürk vd., 2011). Öğrencilerin kişisel bilgileri (cinsiyet, okul türü, anne ve babanın eğitim durumu, rehber öğretmen sayısı) için frekans ve yüzde teknikleri kullanılmıştır. Araştırmaya katılan öğrencilerin cinsiyet, okul, anne babanın eğitim durumu ve rehber öğretmen sayısı değişkenlerine göre, kişisel rehberlik, mes- 
lekî rehberlik, eğitsel rehberlik, rehber öğretmen ve okulun şartları boyutları açısından anlamlı bir fark olup olmadığını belirtmek üzere Mann Whitney $U$ ve Kruskal-Wallis $H$ testi uygulanmıştır. Mann Whitney U Testi ilişkisiz örneklemler için $t$ testinin parametrik olmayan karşılığıdır. Bağımsız iki ortalama arasındaki farkın test edilmesinde kullanılır. Kruskal-Wallis H testi de ilişkisiz örneklemler için tek yönlü varyans analizinin parametrik olmayan karşılığıdır. Bağımsız ikiden fazla ortalama arasındaki farkın test edilmesinde kullanılır (Büyüköztürk vd., 2011).

\section{Bulgular}

Araştırmaya katılan öğrencilerin cinsiyet, okul türü, anne öğrenim durumu, baba öğrenim durumu ve rehber öğretmen sayısı gibi değişkenlerle ilgili bilgiler Tablo 2'de verilmiştir.

Öğrencilerin cinsiyetleri açısından, erkek öğrencilerin (\%52.7) çoğunluğu oluşturduğu görülmektedir. Okul türü açısından en büyük kümeyi anadolu lisesi (\%26.3) öğrencileri oluşturmaktadır. Anne öğrenim durumu açısından ilkokul mezunu (\%33.8) anneler en büyük kümeyi oluştururken, baba öğrenim durumları açısından en büyük kümeyi üniversite mezunu (\%31.6) babalar oluşturmaktadır. Ayrıca okuldaki rehber öğretmen sayısı bir (1) olan öğrenciler (\%73.8) de çoğunluğu oluşturmaktadırlar. 
Tablo 2. Öğrencilere İlişkin Bilgiler

\begin{tabular}{llrr}
\hline Bağımsız Değişken & & N & \% \\
\hline Cinsiyet & Kiz & 231 & 47.3 \\
& Erkek & 257 & 52.7 \\
\hline Okul Türü & Genel Lise & 98 & 20.1 \\
& Fen Lisesi & 90 & 18.4 \\
& Meslek Lisesi & 95 & 19.5 \\
& Anadolu Lisesi & 128 & 26.3 \\
& Anadolu Öğretmen Lisesi & 77 & 15.8 \\
\hline Anne Öğrenim & Okuryazar & 8 & 1.6 \\
Durumu & İkokul Mezunu & 165 & 33.8 \\
& Ortaokul Mezunu & 81 & 16.6 \\
& Lise Mezunu & 131 & 26.8 \\
& Üniversite Mezunu & 103 & 21.1 \\
\hline Baba Öğrenim & Okuryazar & 2 & 0.4 \\
Durumu & İlkokul Mezunu & 87 & 17.8 \\
& Ortaokul Mezunu & 100 & 20.5 \\
& Lise Mezunu & 145 & 29.7 \\
& Üniversite Mezunu & 154 & 31.6 \\
\hline Rehber & 1 & 360 & 73.8 \\
Öğretmen Sayısı & 2 & 128 & 26.2 \\
\hline
\end{tabular}

Cinsiyet, okul türü, anne ve baba eğitim durumu, okuldaki rehber öğretmen sayısına göre öğrenci görüşlerinin, 9. sınıf rehberlik programına ilişkin öğrenci görüşlerinin alt boyutları olan kişisel rehberlik hizmetleri, meslekî rehberlik hizmetleri, eğitsel rehberlik hizmetleri, rehber öğretmen ve okulun şartları puan ortalamalarının farklılaşıp farklılaşmadığ 1 Mann Whitney U ve Kruskal-Wallis H testi ile analiz edilmiştir. 
Tablo 3. Kişisel Rehberlik Hizmetleri Boyutunda Cinsiyet, Okul Türü, Anne ve Baba Eğitim Durumu, Okuldaki Rehber Öğretmen Sayısı Değişkenlerine Göre Öğrenci Görüşleri

\begin{tabular}{llccccc}
\hline Değişken & & N & $\begin{array}{c}\text { Sira } \\
\text { Ortalaması }\end{array}$ & $\begin{array}{c}\text { Sira } \\
\text { Toplamı }\end{array}$ & U & $\boldsymbol{p}$ \\
\hline Cinsiyet & Kız & 231 & 244.4 & 56455.5 & 29659.5 & 0.98 \\
& Erkek & 257 & 244.5 & 62860.5 & & \\
\hline Okul & Genel Lise & 98 & 278.52 & 4 & 46.05 & 0.00 \\
Türü & Fen Lisesi & 90 & 167.17 & & & \\
& Meslek Lisesi & 95 & 258.61 & & & \\
& Anadolu Lisesi & 128 & 230.29 & & & \\
& And. Öğr. Lisesi & 77 & 297.81 & & & 0.006 \\
\hline Anne & Okuryazar & 8 & 233.63 & 4 & 14.39 & \\
Öğrenim & İkokul Mezunu & 165 & 265.46 & & & \\
Durumu & Ortaokul Mezunu & 81 & 269.41 & & & \\
& Lise Mezunu & 131 & 232.79 & & & \\
& Üniversite Mezunu & 103 & 207.06 & & & \\
\hline Baba & Okuryazar & 2 & 158.75 & 4 & 10.24 & 0.036 \\
Öğrenim & İkokul Mezunu & 87 & 263.41 & & & \\
Durumu & Ortaokul Mezunu & 100 & 269.38 & & & \\
& Lise Mezunu & 145 & 243.67 & & & \\
& Üniversite Mezunu & 154 & 219.56 & & 2.45 & 0.11 \\
\hline Rehber & 1 & 359 & 238.05 & 1 & & \\
Öğretmen & 2 & 128 & 260.69 & & & \\
Sayıs1 & & & & & & \\
\hline
\end{tabular}

Öğrencilerin kişisel rehberlik hizmetleri etkinliklerine ilişkin görüşleri cinsiyetlerine göre incelendiğinde, kız ve erkek öğrenciler arasında $(p>0.05)$ anlamlı bir farklılık bulunmadığı görülmektedir. Okul türlerine göre görüşler incelendiğinde ise, okul türleri arasında $(p<0.05)$ anlamlı bir fark olduğu görülmektedir. Sıra ortalamalarına bakıldığgnda anadolu ögretmen lisesinin (297.81) en fazla ortalamaya sahip olduğu görülmektedir. Bu bulgu anadolu öğretmen lisesi öğrencilerinin 9. sınıf rehberlik programında yer alan kişisel rehberlik hizmetlerinin diğer lise öğrencilerine göre daha yararlı olduğunu düşündüklerini göstermektedir. Fen lisesi öğrencileri ise kişisel rehberlik 
hizmetlerinin diğer liselerin öğrencilerine göre daha az yararlı olduğunu düşünmektedirler. Her iki okulun da öğrenci profili birbirine yakın özellikler gösterdiğinden, bu durum okulların rehberlik programını uygulamadaki politikalarına veya programı sistemli bir şekilde uygulamalarına bağlanabilir. Öğrencilerin kişisel rehberlik hizmetleri etkinliklerine ilişkin görüşleri anne öğrenim durumuna göre incelendiğinde, anne öğrenim durumları arasında $(p<0.05)$ anlamlı bir fark olduğu görülmektedir. Anneleri ortaokul mezunu olan öğrencilerin 9. sınıf rehberlik programında yer alan kişisel rehberlik hizmetlerinin diğer öğrencilere göre daha yararlı olduğunu düşündükleri görülmektedir. Annesi üniversite mezunu olan öğrencilerin ise 9. sinıf rehberlik programında yer alan kişisel rehberlik hizmetlerinin diğer öğrencilere göre daha az yararlı olduğunu düşündükleri görülmektedir. Baba öğrenim durumuna göre incelendiğinde, baba öğrenim durumları arasında $(p<0.05)$ anlamlı bir fark olduğu görülmektedir. Babaları ortaokul mezunu olan öğrencilerin 9. sınıf rehberlik programında yer alan kişisel rehberlik hizmetlerinin diğer öğrencilere göre daha yararlı olduğunu düşündükleri görülmektedir. Babası okuryazar olan öğrencilerin ise 9. sınıf rehberlik programında yer alan kişisel rehberlik hizmetlerinin diğer öğrencilere göre daha az yararlı olduğunu düşündükleri görülmektedir. Babası okuryazar olan öğrencilerin ise 9. sinıf rehberlik programında yer alan kişisel rehberlik hizmetlerini diğer öğrencilere göre daha yetersiz buldukları görülmüştür. Okullarındaki rehber öğretmen sayısına göre incelendiğinde, bir ve iki rehber öğretmeni olan okullardaki öğrenciler arasında $p>0.05$ olduğundan anlamlı bir farklılık bulunmadığı görülmektedir. 
Tablo 4. Meslekî Rehberlik Hizmetleri Boyutunda Cinsiyet, Okul Türü, Anne ve Baba Eğitim Durumu, Okuldaki Rehber Öğretmen Sayısı Değişkenlerine Göre Öğrenci Görüşleri

\begin{tabular}{|c|c|c|c|c|c|c|}
\hline Değişken & & $\mathbf{N}$ & $\begin{array}{c}\text { Sira } \\
\text { Ortalaması } \\
\end{array}$ & $\begin{array}{c}\text { Sira } \\
\text { Toplamı }\end{array}$ & $\mathbf{U}$ & $p$ \\
\hline \multirow[t]{2}{*}{ Cinsiyet } & $\mathrm{K} 1 \mathrm{Z}$ & 231 & 243.78 & 56313.00 & 29517.00 & 0.91 \\
\hline & Erkek & 257 & 245.15 & 63003.00 & & \\
\hline Okul & Genel Lise & 98 & 281.85 & 4 & 62.95 & 0.00 \\
\hline \multirow[t]{4}{*}{ Türü } & Fen Lisesi & 90 & 147.14 & & & \\
\hline & Meslek Lisesi & 95 & 250.20 & & & \\
\hline & Anadolu Lisesi & 128 & 245.34 & & & \\
\hline & And. Öğr. Lisesi & 77 & 302.32 & & & \\
\hline Anne & Okuryazar & 8 & 208.94 & 4 & 11.54 & 0.02 \\
\hline Öğrenim & İlkokul Mezunu & 165 & 265.18 & & & \\
\hline \multirow[t]{3}{*}{ Durumu } & Ortaokul Mezunu & 81 & 260.19 & & & \\
\hline & Lise Mezunu & 131 & 238.11 & & & \\
\hline & Üniversite Mezunu & 103 & 209.91 & & & \\
\hline Baba & Okuryazar & 2 & 131.25 & 4 & 12.32 & 0.01 \\
\hline Öğrenim & İlkokul Mezunu & 87 & 258.21 & & & \\
\hline \multirow{3}{*}{ Durumu } & Ortaokul Mezunu & 100 & 249.60 & & & \\
\hline & Lise Mezunu & 145 & 265.73 & & & \\
\hline & Üniversite Mezunu & 154 & 214.92 & & & \\
\hline Rehber & 1 & 359 & 243.55 & 1 & 0.01 & 0.90 \\
\hline $\begin{array}{l}\text { Öğretmen } \\
\text { Sayıs1 }\end{array}$ & 2 & 128 & 245.27 & & & \\
\hline
\end{tabular}

Öğrencilerin meslekî rehberlik hizmetleri etkinliklerine ilişkin görüşleri cinsiyetlerine göre incelendiğinde, kız ve erkek öğrenciler arasında $(p>0.05)$ anlamlı bir farklılık bulunmadığı görülmektedir. Okul türlerine göre incelendiğinde, okul türleri arasında $(p<0.05)$ anlamlı bir fark olduğu görülmektedir. Anadolu öğretmen lisesi öğrencilerinin 9. sınıf rehberlik programında yer alan meslekî rehberlik hizmetlerinin diğer lise öğrencilerine göre daha yararlı olduğunu düşündükleri görülmektedir. Anne öğrenim durumuna göre incelendiğinde, anne öğrenim durumları arasında $(p<0.05)$ olduğundan anlamlı bir fark olduğu görülmektedir. Anneleri ilkokul mezunu olan öğrencilerin 9. 
sınıf rehberlik programında yer alan meslekî rehberlik hizmetlerinin diğer öğrencilere göre daha yararlı olduğunu düşündükleri görülmektedir. Annesi okuryazar olan öğrencilerin ise 9. sinıf rehberlik programında yer alan meslekî rehberlik hizmetlerinin diğer öğrencilere göre daha az yararlı olduğunu düşündükleri görülmektedir. Baba öğrenim durumları arasında ( $p<0.05)$ anlamlı bir fark olduğu görülmektedir. Babaları lise mezunu olan öğrencilerin 9. sınıf rehberlik programında yer alan meslekî rehberlik hizmetlerinin diğer öğrencilere göre daha yararlı olduğunu düşündükleri görülmektedir. Babası okuryazar olan öğrencilerin ise 9. sınıf rehberlik programında yer alan meslekî rehberlik hizmetlerini diğer öğrencilere göre daha yetersiz buldukları görülmüştür. Okullardaki rehber öğretmen sayısına göre incelendiğinde, bir ve iki rehber öğretmeni olan okullardaki öğrenciler arasında ( $p>0.05)$ anlamlı bir farklılık bulunmadığg görülmektedir.

Öğrencilerin eğitsel rehberlik hizmetleri etkinliklerine ilişkin görüşleri cinsiyetlerine göre incelendiğinde, kız ve erkek öğrenciler arasında ( $p>0.05)$ anlamlı bir farklılık bulunmadığı görülmektedir. Okul türlerine göre incelendiğinde, okul türleri arasında $(p<0.05)$ anlamlı bir fark olduğu görülmektedir. Anadolu öğretmen lisesi öğrencilerinin 9. sınıf rehberlik programında yer alan eğitsel rehberlik hizmetlerinin diğer lise öğrencilerine göre daha yararlı olduğunu düşündükleri görülmektedir. Anne öğrenim durumuna göre incelendiğinde, anne öğrenim durumları arasında $(p>0.05)$ olduğundan anlamlı bir farklılık bulunmadığı görülmektedir. Baba öğrenim durumuna göre incelendiğinde, baba öğrenim durumları arasında $(p<0.05)$ anlamlı bir fark olduğu görülmektedir. Babaları ortaokul mezunu olan öğrencilerin 
9. sınıf rehberlik programında yer alan eğitsel rehberlik hizmetlerinin diğer öğrencilere göre daha yararlı olduğunu düşündükleri görülmektedir. Rehber öğretmen sayısına göre incelendiğinde, bir ve iki rehber öğretmeni olan okullardaki öğrenciler arasında $(p>0.05)$ anlamlı bir farklılık bulunmadığı görülmektedir.

Tablo 5. Eğitsel Rehberlik Hizmetleri Boyutunda Cinsiyet, Okul Türü, Anne ve Baba Eğitim Durumu, Okuldaki Rehber Öğretmen Sayısı Değişkenlerine Göre Öğrenci Görüşleri

\begin{tabular}{|c|c|c|c|c|c|c|}
\hline Değişken & & $\mathbf{N}$ & $\begin{array}{c}\text { Sira } \\
\text { Ortalaması } \\
\end{array}$ & $\begin{array}{c}\text { Sira } \\
\text { Toplamı } \\
\end{array}$ & $\mathbf{U}$ & $p$ \\
\hline Cinsiyet & $\begin{array}{l}\text { K1z } \\
\text { Erkek }\end{array}$ & $\begin{array}{l}231 \\
257\end{array}$ & $\begin{array}{l}253.25 \\
236.63\end{array}$ & $\begin{array}{l}58501.00 \\
60815.00\end{array}$ & 27662.00 & 0.19 \\
\hline $\begin{array}{l}\text { Okul } \\
\text { Türü }\end{array}$ & $\begin{array}{l}\text { Genel Lise } \\
\text { Fen Lisesi } \\
\text { Meslek Lisesi } \\
\text { Anadolu Lisesi } \\
\text { And. Öğr. Lisesi } \\
\end{array}$ & $\begin{array}{c}98 \\
90 \\
95 \\
128 \\
77 \\
\end{array}$ & $\begin{array}{l}262.14 \\
177.41 \\
231.42 \\
260.88 \\
289.38 \\
\end{array}$ & 4 & 32.37 & 0.00 \\
\hline $\begin{array}{l}\text { Anne } \\
\text { Öğrenim } \\
\text { Durumu }\end{array}$ & $\begin{array}{l}\text { Okuryazar } \\
\text { İlkokul Mezunu } \\
\text { Ortaokul Mezunu } \\
\text { Lise Mezunu } \\
\text { Üniversite Mezunu }\end{array}$ & $\begin{array}{c}8 \\
165 \\
81 \\
131 \\
103\end{array}$ & $\begin{array}{l}256.25 \\
260.20 \\
265.15 \\
231.26 \\
219.02\end{array}$ & 4 & 8.38 & 0.78 \\
\hline $\begin{array}{l}\text { Baba } \\
\text { Öğrenim } \\
\text { Durumu }\end{array}$ & $\begin{array}{l}\text { Okuryazar } \\
\text { İlkokul Mezunu } \\
\text { Ortaokul Mezunu } \\
\text { Lise Mezunu } \\
\text { Üniversite Mezunu }\end{array}$ & $\begin{array}{c}2 \\
87 \\
100 \\
145 \\
154\end{array}$ & $\begin{array}{l}153.25 \\
259.17 \\
273.10 \\
245.18 \\
218.18\end{array}$ & 4 & 11.30 & 0.02 \\
\hline $\begin{array}{l}\text { Rehber } \\
\text { Öğretmen } \\
\text { Say1sı }\end{array}$ & $\begin{array}{l}1 \\
2\end{array}$ & $\begin{array}{l}359 \\
128\end{array}$ & $\begin{array}{l}238.05 \\
260.69\end{array}$ & 1 & 2.45 & 0.11 \\
\hline
\end{tabular}


Tablo 6. Rehber Öğretmen Boyutunda Cinsiyet, Okul Türü, Anne ve Baba Eğitim Durumu, Okuldaki Rehber Öğretmen Sayısı Değişkenlerine Göre Öğrenci Görüşleri

\begin{tabular}{|c|c|c|c|c|c|c|}
\hline Değişken & & $\mathbf{N}$ & $\begin{array}{c}\text { Sira } \\
\text { Ortalaması }\end{array}$ & $\begin{array}{c}\text { Sira } \\
\text { Toplamı }\end{array}$ & $\mathbf{U}$ & $p$ \\
\hline \multirow[t]{2}{*}{ Cinsiyet } & $\mathrm{K}_{1 \mathrm{Z}}$ & 231 & 250.27 & 57811.50 & 28351.20 & 0.39 \\
\hline & Erkek & 257 & 239.32 & 61504.50 & & \\
\hline \multirow[t]{5}{*}{ Okul Türü } & Genel Lise & 98 & 275.36 & 4 & 35.241 & 0.00 \\
\hline & Fen Lisesi & 90 & 195.52 & & & \\
\hline & Meslek Lisesi & 95 & 220.22 & & & \\
\hline & Anadolu Lisesi & 128 & 234.70 & & & \\
\hline & And. Öğr. Lisesi & 77 & 308.72 & & & \\
\hline Anne & Okuryazar & 8 & 213.63 & 4 & 2.43 & 0.65 \\
\hline Öğrenim & İlkokul Mezunu & 165 & 251.29 & & & \\
\hline \multirow[t]{3}{*}{ Durumu } & Ortaokul Mezunu & 81 & 258.10 & & & \\
\hline & Lise Mezunu & 131 & 234.12 & & & \\
\hline & Üniversite Mezunu & 103 & 238.52 & & & \\
\hline Baba & Okuryazar & 2 & 100.75 & 4 & 5.69 & 0.22 \\
\hline Öğrenim & İlkokul Mezunu & 87 & 226.84 & & & \\
\hline \multirow[t]{3}{*}{ Durumu } & Ortaokul Mezunu & 100 & 264.89 & & & \\
\hline & Lise Mezunu & 145 & 246.56 & & & \\
\hline & Üniversite Mezunu & 154 & 241.17 & & & \\
\hline Rehber & 1 & 359 & 247.36 & 1 & 0.78 & 0.37 \\
\hline Öğretmen & 2 & 128 & 234.57 & & & \\
\hline Sayıs1 & & & & & & \\
\hline
\end{tabular}

Öğrencilerin okul ve sınıf rehber öğretmenlerine ilişkin görüşleri cinsiyetlerine göre incelendiğinde, kız ve erkek öğrenciler arasında ( $p>0.05)$ anlamlı bir farklılık bulunmadığı görülmektedir. Okul türlerine göre incelendiğinde, okul türleri arasında $(p<0.05)$ anlamlı bir fark olduğu görülmektedir. Anadolu öğretmen lisesi öğrencilerinin 9. sınıf rehberlik programının uygulanması sırasında, okul ve sınıf rehber öğretmeninin daha istekli olduğu ve öğrencileri kısmen daha iyi takip ettiklerini düşündükleri görülmektedir. Anne öğrenim durumuna göre incelendiğinde, anne öğrenim durumları arasında $(p>0.05)$ anlamlı bir farklılık bulunmadığı görülmektedir. Baba öğrenim durumuna göre 
incelendiğinde, baba öğrenim durumları arasında $(p>0.05)$ anlamlı bir farklılık bulunmadığ 1 görülmektedir. Rehber öğretmen sayısına göre incelendiğinde ise, bir ve iki rehber öğretmeni olan okullardaki öğrenciler arasında $(p>0.05)$ anlamlı bir farklılık bulunmadığı görülmektedir.

Tablo 7. Okulun Şartları Boyutunda Cinsiyet, Okul Türü, Anne ve Baba Eğitim Durumu, Okuldaki Rehber Öğretmen Sayısı Değişkenlerine Göre Öğrenci Görüşleri

\begin{tabular}{|c|c|c|c|c|c|c|}
\hline Değişken & & $\mathbf{N}$ & $\begin{array}{c}\text { Sira } \\
\text { Ortalaması }\end{array}$ & $\begin{array}{c}\text { Sira } \\
\text { Toplamı }\end{array}$ & $\mathbf{U}$ & $p$ \\
\hline \multirow[t]{2}{*}{ Cinsiyet } & Kiz & 231 & 241.91 & 55881.50 & 29085.50 & 0.70 \\
\hline & Erkek & 257 & 246.83 & 63434.50 & & \\
\hline Okul & Genel Lise & 98 & 249.17 & 4 & 9.48 & 0.05 \\
\hline \multirow[t]{4}{*}{ Türü } & Fen Lisesi & 90 & 228.87 & & & \\
\hline & Meslek Lisesi & 95 & 243.65 & & & \\
\hline & Anadolu Lisesi & 128 & 228.01 & & & \\
\hline & And. Öğr. Lisesi & 77 & 285.29 & & & \\
\hline Anne & Okuryazar & 8 & 167.94 & 4 & 9.98 & 0.04 \\
\hline Öğrenim & İlkokul Mezunu & 165 & 262.39 & & & \\
\hline \multirow[t]{3}{*}{ Durumu } & Ortaokul Mezunu & 81 & 213.03 & & & \\
\hline & Lise Mezunu & 131 & 237.84 & & & \\
\hline & Üniversite Mezunu & 103 & 255.01 & & & \\
\hline Baba & Okuryazar & 2 & 139.25 & 4 & 2.16 & 0.70 \\
\hline Öğrenim & İlkokul Mezunu & 87 & 236.07 & & & \\
\hline \multirow[t]{3}{*}{ Durumu } & Ortaokul Mezunu & 100 & 247.67 & & & \\
\hline & Lise Mezunu & 145 & 240.07 & & & \\
\hline & Üniversite Mezunu & 154 & 252.74 & & & \\
\hline Rehber & 1 & 359 & 249.76 & 1 & 2.30 & 0.12 \\
\hline Öğretmen & 2 & 128 & 227.86 & & & \\
\hline Sayıs1 & & & & & & \\
\hline
\end{tabular}

Öğrencilerin okulun şartlarına ilişkin görüşleri cinsiyetlerine göre incelendiğinde, kız ve erkek öğrenciler arasında $(p>0.05)$ anlamlı bir farklılık bulunmadığı görülmektedir. Okul türlerine göre incelendiğinde, okul türleri arasında öğrenci görüşlerinin anlamlı bir farklılık 
göstermediği $(p=0.05)$ eşitlik olduğu görülmüştür. Ancak 0.01 düzeyinde anlamlı farklılık göstermektedir. Bununla birlikte sira ortalamalarına bakıldığında anadolu öğretmen lisesi öğrencilerinin lehine anlamlı bir fark vardır denilebilir. Anne öğrenim durumuna göre incelendiğinde, anne öğrenim durumları arasında $(p<0.05)$ anlamlı bir fark olduğu görülmektedir. Anneleri ilkokul mezunu olan öğrencilerin, okulun şartlarına ilişkin olarak diğer öğrencilere göre bu şartların daha yeterli olduğunu düşündükleri görülmektedir. Baba öğrenim durumuna göre incelendiğinde, baba öğrenim durumları arasında $(p>0.05)$ anlamlı bir farklılık bulunmadığı görülmektedir. Okullarındaki rehber öğretmen sayısına göre incelendiğinde, bir ve iki rehber öğretmeni olan okullardaki öğrenciler arasında $p>0.05$ olduğundan anlamlı bir farklılık bulunmadığı görülmektedir.

\section{Sonuçlar ve Tartışma}

9. sınıf öğrencilerine yönelik olarak hazırlanan rehberlik programının öğrenci görüşlerine göre etkililiğinin değerlendirilmesi amacıyla gerçekleştirilen bu araştırmada, öğrencilerin 9. sınıf rehberlik programında yer alan "Kişisel Rehberlik Hizmetlerini” orta seviyede etkili gördükleri sonucu ortaya çıkmıştır. Çeşitli değişkenlere göre sonuçların farklılaşma düzeyleri incelendiğinde ise cinsiyet ve okuldaki rehber öğretmen sayısı değişkenleri açısından anlamlı bir farklılık bulunamamıştır. Okul türü değişkeni açısından ise anadolu öğretmen lisesi öğrencilerinin kişisel rehberlik hizmetlerini diğer lise öğrencilerine göre daha yararlı buldukları sonucu ortaya çıkmıştır. Anne öğrenim durumu ve baba öğrenim durumu açısından bakıldığında annesi ve 
babası ortaokul mezunu olan öğrencilerin kişisel rehberlik hizmetlerini daha yararlı buldukları, bunu, annesi ve babası ilkokul mezunu olan öğrencilerin takip ettiği sonucuna ulaşılmıştır. Bulgulara göre anne ve babasının eğitim seviyesi düşük olan öğrencilerin, ailelerinden yeterli seviyede destek ve yardım göremedikleri, bu nedenle kişisel rehberlik hizmetlerinden daha çok yararlandıkları söylenebilir. Bardakçı (2011) da ilgili araştırmasında, kişisel ve sosyal alanlardaki rehberlik etkinliklerinin daha yararlı olduğu sonucuna ulaşmıştır. Demiç ve Kılıç (2006) da araştırmasında ilk ve ortaöğretimde uygulanan rehberlik çalışmalarının öğrencilerin benlik algısının farklılaşmasında etkili olduğu sonucuna ulaşmıştır. Rehberlik çalışmalarına katılan öğrencilerin benlik algılarının daha olumlu gerçekleştiği görülmüştür. Topses’e (2007) göre de kişisel rehberlik, öğrencilerin gelişimsel özelliklerini dikkate alarak onlara psikolojik yardımda bulunmayı hedeflemektedir. Eğitim süreci içinde öğrencinin kendini tanıması, kendini kabul etmesi, güçlü ve zayıf yönlerini ayırt edebilmesi, kişiler arası ilişkilerinde dengeli olması, kişisel ve sosyal açıdan uyumlu bir birey olarak yetişmesi amaçlanır. Okullarda imkânlar dâhilinde sosyal beceri eğitimi, iletişim becerileri eğitimi, özsayg1 ve özgüven geliştirme eğitimi, atılganlık eğitimi gibi kişisel rehberlik etkinliklerine yer verilebilir.

Araştırmaya katılan öğrenciler 9. sınıf rehberlik programında yer alan "Meslekî Rehberlik Hizmetlerini” orta seviyede etkili buldukları yönünde görüş belirtmişlerdir. Çeşitli değişkenlere göre sonuçların farklılaşma seviyeleri incelendiğinde cinsiyet ve okuldaki rehber öğ- 
retmen sayısı değişkenleri açısından anlamlı bir farklılık bulunamamıştır. Okul türü değişkeni açısından anadolu öğretmen lisesi öğrencilerinin meslekî rehberlik hizmetlerini diğer lise öğrencilerine göre daha yararlı buldukları sonucu ortaya çıkmıştır. Anne öğrenim durumları açısından bulgular incelendiğinde de annesi ilkokul mezunu olan öğrencilerin meslekî rehberlik hizmetlerini daha yararlı bulduklar1, bunu annesi ortaokul mezunu olan öğrencilerin takip ettiği sonucuna ulaşılmıştır. Baba öğrenim durumlarına göre bulgular incelendiğinde, babası lise mezunu olan öğrencilerin meslekî rehberlik hizmetlerini daha yararlı buldukları sonucuna ulaşılmıştır. Anne ve babanın eğitim seviyesi düştükçe çocuklarını meslekler ve meslek seçimi konusunda yeterince bilgilendiremedikleri ve bu sebeple daha çok, okulun sunduğu meslekî rehberlik eğitiminden yararlandıkları yorumu yapılabilir. Tokalı (2007)'nın, 9. sınıf rehberlik programının değerlendirilmesi amacıyla yürüttüğü araştırmasında araştırmaya katılan rehber öğretmenlerin \%60'1 programın meslekler hakkında bilgilendirmesi, meslekî eğitim alanında bilgi vermesi, iyi bir mesleğe yöneltmesi, mesleklerin tanıtılması, meslekî anlamda öğrencilere yön vermesi gerektiğini belirtmişlerdir. Ayrıca 9. sınıf öğrencilerinin ilgi ve yeteneklerine göre alan seçimi, uygun alana yönelme gibi konularda bilgilendirmelerin olması ve ilgili değişikliklerin yapılması önerilmiştir. Peker (2008), farklı liselerdeki öğrenci, öğretmen ve yöneticilerin rehberlik beklentilerini değerlendirdiği araştırmasında, farklı rehberlik alanlarında beklentilerin farklılaşıp farklılaşmadığına ilişkin olarak öğretmenlerin meslekî rehberlik hizmet alanından beklentilerinin öğrencilere ve eğitsel, kişisel rehberlik hizmetlerine göre daha yüksek olduğu sonu- 
cuna ulaşmıştır. Can (2005) da okullarda yürütülebilecek rehberlik hizmetleriyle öğrencilerin kendi kişisel ve eğitsel özelliklerine uygun katkı sağlanması gerektiğini vurgulamaktadır.

Eğitsel rehberlik hizmetlerinin etkililiğine ilişkin olarak araştırmaya katılan öğrencilerin görüşlerinin orta seviyede çıtığı görülmektedir. Çeşitli değişkenlere göre eğitsel rehberlik hizmetlerinin etkililiğine ilişkin görüşlerin farklılaşma seviyeleri incelendiğinde ise cinsiyet, anne öğrenim durumu ve okuldaki rehber öğretmen sayısı değişkenleri açısından anlamlı bir farklılık bulunamamıştır. Ancak Hıdır (2010), bu araştırma bulgularının aksine rehberlik hizmetlerinin eğitsel başarı alt boyutunda, kızların lehine anlamlı farklılık bulmuştur. Okul türü değişkeni açısından anadolu öğretmen lisesi öğrencilerinin eğitsel rehberlik hizmetlerini diğer lise öğrencilerine göre daha yararlı buldukları sonucu ortaya çıkmıştır. Benzer biçimde, Tatlıoğlu (1999) da rehberlik ve psikolojik danışmanlık servisinden beklentiler üzerine yürüttüğü araştırmasında okul türlerine göre öğrencilerin beklentilerinin farklılaştığı bulgusuna ulaşmıştır. Buna göre, ticaret lisesi, anadolu lisesi, endüstri meslek lisesi ve genel lise öğrencilerinin rehberlik servisinden beklentilerinin yüksek olduğu; imam-hatip lisesi, süper lise, teknik lise ve kız meslek lisesi öğrencilerinin beklentilerinin ise düşük olduğu sonucuna varmıştır. Baba öğrenim durumlarına göre bulgular incelendiğinde babası ortaokul mezunu olan öğrencilerin eğitsel rehberlik hizmetlerini daha yararlı buldukları sonucuna ulaşılmıştır. Buna göre, babanın eğitim seviyesi düştükçe öğrencilerin okulun sunduğu eğitsel rehberlik hizmetlerinden daha çok yararlanma ihtiyacı hisset- 
tikleri söylenebilir. Avcı (2006), sınıf içi rehberlik etkinliklerinin öğrencilerin verimli ders çalışma alışkanlıkları üzerindeki etkisini araştırmıştır. Araştırmanın sonucuna göre, sınıf içi rehberlik etkinliklerine katılan öğrencilerin etkinlikler sonrasında çalışma alışkanlıklarında olumlu gelişmeler meydana geldiği görülmüştür. Bununla beraber, öğrencilerin akademik başarılarının yükseldiğgi, sınav kaygılarının da düştüğü görülmüştür. Balcı (2012), eğitsel rehberliğin, öğrencinin gereken başarıyı gösterebilmesi için etkili ders çalışma yöntemlerini kavraması, ders çalışma alışkanlıkları kazanması, iç ve dış motivasyonunu sağlanması gibi konulardan oluştuğunu belirtmektedir. Okula yeni kayıt yaptıran öğrencilerin okula uyum süreçlerini sağlıklı bir şekilde geçirmelerine yardım etmek, seçtikleri sınıf ya da alanda karşılaştıkları sorunlarla baş edebilmelerine yardım etmek ve bireysel farkl11ıkları yönünde ulaşabilecekleri en üst başarı seviyesine ulaşmalarına yardım etmek, eğitsel rehberliğin başlıca uğraşı alanı olarak gösterilmiştir.

Araştırmaya katılan öğrencilerin 9. sınıf rehberlik programının uygulanması sırasında okul ve sınıf rehber öğretmenlerinin, öğrencileri kişisel, sosyal ve akademik olarak takip edebilmelerini ve uygulamalara ilişkin olarak istekli olma durumlarını orta seviyede yeterli buldukları sonucuna ulaşılmıştır. Çeşitli değişkenlere göre sonuçların farklılaşma seviyeleri incelendiğinde ise cinsiyet, anne öğrenim durumu, baba öğrenim durumu ve okuldaki rehber öğretmen sayısı değişkenleri açısından anlamlı bir farklılık bulunamamıştır. Bununla beraber okul türü değişkeni açısından anadolu öğretmen lisesi öğren- 
cilerinin okul ve sınıf öğretmenlerini çeşitli yönleriyle takip edebilmeleri ve uygulamalara karşı istekli olma durumlarını diğer lise öğrencilerine göre daha etkili buldukları sonucu ortaya çıkmıştır. Eşen (2009), 10. sınıflar için hazırlanan rehberlik programının değerlendirilmesi amacıyla yürüttüğü araştırmasını rehber öğretmenlerin görüşlerine göre incelemiştir. Rehber öğretmenler, sınıf rehber öğretmenlerinin daha etkin olması gerektiği yönünde görüş bildirmişlerdir. Programda bir değişiklik yapılmasından çok, uygulayıcıların sayısının artırılmasını önermişlerdir. Sınıf rehber öğretmenleriyle diğer branş öğretmenlerinin daha etkin olması gerektiğini ve rehberlik programıla ilgili eğitimden geçirilmeleri gerektiğini önermişlerdir. Tan (1992) ise, rehberlik programının başarısını, sınıf rehber öğretmenlerinin programa katılma ve işbirliği derecesine bağlı olduğunu vurgulamıştır.

Araştırmaya katılan öğrencilerin 9. sınıf rehberlik programının uygulanması sırasında okuldaki rehber öğretmen sayısının yeterli olması, rehberlik etkinliklerinin uygulanabilmesi için haftada bir ders saatinin yeterli olması ve okul idaresinin gerektiğince destekleyici ve yardımcı olmasını orta seviyede yeterli bulmuşlardır. Türlü değişkenlere göre sonuçların farklılaşma seviyeleri incelendiğinde ise cinsiyet, baba öğrenim durumu, okul türü ve okuldaki rehber öğretmen sayıs1 değişkenleri açısından anlamlı bir farklılık bulunamamıştır. Anne öğrenim durumlarına göre bulgular incelendiğinde, annesi ilkokul mezunu olan öğrenciler, okulun programı uygulamasına ilişkin şartları, diğerlerine göre daha yeterli bulmaktadırlar. Poyraz (2007), orta dereceli okullarda uygulanan rehberlik hizmetleri üzerine yürüttüğü araş- 
tırmasında, psikolojik danışmanı olan okullardaki rehberlik hizmetlerinin, olmayan okullardaki rehberlik hizmetlerine göre daha üst seviyede gerçekleştirildiği sonucuna ulaşmıştır. Psikolojik danışman sayısı arttıkça rehberlik hizmetlerinin puanının da yükseldiği görülmüştür. Okullarda rehber öğretmen bulunması ve sayısı kadar, diğer personelin programa katılımı da oldukça önemlidir. Külahoğlu (2004) da bu konuda sınıf öğretmenlerinin, okul-aile birliklerinin, okul idarecileri gibi pek çok eğitim paydaşlarının, okul rehberlik programının yürütülmesinde destekleyici elemanlar olduğunu belirlemektedir. Ayrıca Kızıl (2007) da ortaöğretim kurumlarındaki rehber öğretmen ve sınıf öğretmenlerinin sınıf içi rehberlik etkinliklerine ilişkin görüşlerini incelediği araştırmasında benzer noktalara değinmiştir. Araştırma sonucunda, rehberlik etkinliklerinde yeterli seviyede işbirliğinin sağlanamadığı, daha verimli hâle getirilebilmesi için işbirliğinin tam anlamıyla sağlanması, öğretmenlerin tam olarak bilgilendirilmeleri, rehber öğretmenlerin daha faal olmaları ve rehberlik etkinliklerinin sürekli ve etkili olması gerektiği görülmüştür.

\section{Kaynakça}

Akbaba, S. (2004). Psikolojik sağlı̆̆ koruyucu rehberlik ve psikolojik danışma. Ankara: Pegem A Yayınları.

Aluede, O. ve Egbochuku, E. (2009). Teacher's opinions of school counseling programs in Nigerian secondary schools. Educational Research Quarterly. 33(1), 42-59.

Avcı, Y. (2006). Sınıf içi rehberlik etkinliklerinin öğrencilerin verimli ders çalışma alışkanlıkları üzerindeki etkisi. Yayınlanmamış yüksek lisans tezi, Balıkesir Üniversitesi Sosyal Bilimler Ensti- 
tüsü.

Aydın, S. (1998). Eğitimde uygulamalı rehberlik. Ankara: Barış Kitap Yayın Dağıtım.

Balc1, S. (2012). Psikolojik danışma ve rehberlik. A. Kaya, (Ed.), Eğitsel rehberlik içinde (83-123). Ankara: Anı Yayıncılık.

Bardakçı, A. (2011). İlköğretim okullarında çalışan sınıf öğretmeni, sinuf rehber ögretmeni ve psikolojik danışmanların kapsamlı gelişimsel rehberlik programına ilişkin görüşleri. Yayınlanmamış yüksek lisans tezi, Çukurova Üniversitesi Sosyal Bilimler Enstitüsü.

Başaran, M. (2008). Illköğretim okullarındaki yönetici ve sinıf rehber ögretmenlerinin psikolojik danışma ve rehberlik faaliyetlerinden beklentileri. Yayınlanmamış yüksek lisans tezi, Yeditepe Üniversitesi Sosyal Bilimler Enstitüsü.

Berber, D. (2010). Ortaöğretim kurumları onuncu sinıf rehberlik programı uygulamalarının sinıf rehber ögretmenleri ve rehber ögretmenler görüşleri doğrultusunda değerlendirilmesi. Yayınlanmamış yüksek lisans tezi, Erciyes Üniversitesi Eğitim Bilimleri Enstitüsü.

Büyüköztürk, Ş. (2011). Veri analizi el kitabı. Ankara: Pegem Akademi.

Büyüköztürk, Ş., Çokluk, Ö. ve Köklü, K. (2011). Sosyal bilimler için istatistik. Ankara, Pegem Akademi.

Chireshe, R. (2006). An assessement of the effectiveness of school guidance and counselling services in Zimbabwean secondary schools. Yayınlanmamış doktora tezi, University Of South Africa. 
Can, G. (2005). Psikolojik danışma ve rehberlik. Ankara, Pegem A Yayıncilik.

Çam, S. (2005). Okullarda rehberlik hizmet alanları birimleri. G. Can, (Ed.), Psikolojik danışma ve rehberlik içinde (53-80). Ankara: Pegem Yayıncılık.

Dahir, C. A., Burnham, J. J. ve Stone, S. (2009). Listen tothe voices: School counselors and comprehensive school counseling programs. Professional School Counseling, 12(3), 182-192.

Demiç, S. ve Kılıç, A. (2006). İlköğretim ve ortaöğretimde uygulanılan rehberlik çalışmalarının ögrencilerin benlik algıları üzerindeki etkisi: Niğde örneği. Yayınlanmamış yüksek lisans tezi, Niğde Üniversitesi Sosyal Bilimler Enstitüsü.

Eşen, R. (2009). 10. sınıf rehberlik programının 'sınıf öğretmenleri için' rehber öğretmen görüşleri doğrultusunda değerlendirilmesi. Yayınlanmamış yüksek lisans tezi, Selçuk Üniversitesi Sosyal Bilimler Enstitüsü.

Girgin, G. (2012). Psikolojik danışma ve rehberlik. A. Kaya, (Ed.), Çăgdaş eğitim sistemlerinde öğrenci kişilik hizmetleri ve rehberlik içinde (1-33). Ankara: Anı Yayıncılık.

Hatipoğlu, H. (2010). Okullarda yürütülen psikolojik danışma ve rehberlik uygulamalarının belirlenmesi ve bazı değişkenler açısından incelenmesi. Yayınlanmamış yüksek lisans tezi, Çukurova Üniversitesi Sosyal Bilimler Enstitüsü.

Hıdır, A. (2010). Ortaögretim kurumlarında sunulan rehberlik hizmetlerinin öğrenci kazanımlarının amacına ulaşma düzeyi. Yayınlanmamış yüksek lisans tezi, Yeditepe Üniversitesi Sosyal Bilimler Enstitüsü.

Karaca, R. ve İkiz, E. (2014). Psikolojik danışma ve rehberlikte çağdaş 
bir anlayış. Ankara: Nobel Yayıncılık.

Kız1l, D. (2007). Ortaöğretim kurumlarındaki rehber öğretmenlerin ve sınıf ögretmenlerinin sınıf içi rehberlik etkinlikleri ile ilgili görüşleri. Yayınlanmamış yüksek lisans tezi, Selçuk Üniversitesi Sosyal Bilimler Enstitüsü.

Kuzgun, Y. (1991). Rehberlik ve psikolojik danışma (4. bask1). Ankara: ÖSYM Yayınları.

Külahoğlu, Ş. (2004). Okul psikolojik danışmanlık ve rehberlik programlarının geliştirilmesi (2. baskı). Ankara: Pegem A Yayıncılık.

Lapan, R. T., Gysbers, N. C. ve Sun, Y. (1997). The impact of morefully implemented guidance programs on the school experiences of high school students: A statewide evaluation study. Journal of Counselingand Development, 75(4), 292-302.

Milli Eğitim Bakanlığı (2011). Ortaöğretim rehberlik ve yönlendirme dersi programı. Talim Terbiye Kurulu Kararı, Sayı:37.

Modo, F., Sanni, K., Uwah, C., ve Mogbo, I. (2013). Guidance and counseling services in secondary school as coping strategy for improved academic performance of students in Akwa Ibom State, Nigeria. Research on Humanities and Social Sciences, 3(4), 43-47. 29 Mayis 2014, http://en.calameo.com/books/0011286835ab08d5b9036.

Muango, G. ve Joel, J. P. O. (2012). An evaluation of the effectiveness of guidance and counselling services in public universities in Kenya. Journal of Emerging Trends in Educational Research and Policy Studies, 3(2), 151-154.

Oğuz, O., Oktay, A. ve Ayhan, H. (2010). 21. yüzyılda eğitim ve Türk eğitim sistemi. Ankara: Pegem Yayıncılık. 
Peker, A. (2008). Farklı liselerdeki öğrenci, ögrretmen ve yöneticilerin rehberlik beklentilerinin bazı değişkenler açısından incelenmesi. Yayınlanmamış yüksek lisans tezi, Atatürk Üniversitesi Sosyal Bilimler Enstitüsü.

Poyraz, C. (2007). Okullarda yürütülen rehberlik hizmetleri üzerine bir araştırma. Yayınlanmamış doktora tezi, İstanbul Üniversitesi Sosyal Bilimler Enstitüsü.

Rowley, W., Stroh, J., Heather, R., S. ve Christopher A. (2005). Comprehensive guidance and counseling programs' use of guidance curricula materials: A survey of national trends. Proffessional School Counseling, 8(4), 296-303.

Selen, N. (2008). Liselerdeki psikolojik danışma ve rehberlik servislerinin algllanan etkililiğinin bazı değişkenlere göre incelenmesi. Yayınlanmamış yüksek lisans tezi, Ege Üniversitesi Sosyal Bilimler Enstitüsü.

Senemoğlu, N. (2011). Gelişim ögrenme ve öğretim kuramdan uygulamaya. (19. bask1). Ankara: Pegem Yayınları.

Şahin, E. (2006). Ortaöğretim rehberlik çalışmalarının üniversitedeki alan seçimine etkisi. Yayınlanmamış yüksek lisans tezi, Yüzüncü Y1l Üniversitesi Sosyal Bilimler Enstitüsü.

Tan, H. (1992). Psikolojik danışma ve rehberlik (3. bask1). İstanbul: Alkım Yayınevi.

Tatlıoğlu, K. (1999). Rehberlik ve psikolojik danışmanlık servisinden beklentiler üzerine bir araştırma. Yayınlanmamış yüksek lisans tezi, Selçuk Üniversitesi Sosyal Bilimler Enstitüsü.

Tokalı, H. (2007). 9. Sinıf rehberlik programının (sınıf ögretmenleri için) rehber ögrretmen görüşleri doğrultusunda değerlendirilmesi. Yayınlanmamış yüksek lisans tezi, Selçuk Üniversitesi Sosyal 
Bilimler Enstitüsü.

Topses, G. (2007). Psikolojik yardım hizmetleri kuram ve uygulamalar. Ankara: Nobel Yayınları.

Tüfekçi, M. (2011). Kapsamlı psikolojik danışma ve rehberlik etkinliklerinin sinıf rehber ögretmenleri ve rehber öğretmenleri tarafindan kullanılma durumları. Yayınlanmamış Yüksek lisans tezi, Gazi Üniversitesi Eğitim Bilimleri Enstitüsü.

Yeşilyaprak, B. (2001). Ĕgitimde rehberlik hizmetleri (2. baskı). Ankara: Nobel Yayın Dağıtım.

Yeşilyaprak, B. (2011). Mesleki rehberlik ve kariyer danışmanlığı. Ankara: Pegem A Yayıncılık. 